\title{
POLSKIE I UKRAIŃSKIE NAZWY PRODUCENTÓW SŁODYCZY I ICH WYROBÓW W UJĘCIU KONTRASTYWNYM
}

Słowa tematyczne: chrematonimy, marka, submarka, nazwy słodyczy, komunikat nazewniczy

\section{WPROWADZENIE}

Pierwsze słodkie przysmaki znane były w starożytnych Chinach, Indiach, na środkowym Wschodzie oraz w Egipcie, chociaż w ich składzie nie znajdował się cukier, lecz miód. Funkcje smakołyków pełniły wówczas zanurzone w miodzie owoce, kwiaty, orzechy, migdały. Jadano także konfitury i galaretki wyrabiane z pigwy, nasion szyszki sosnowej, róży, jabłek, gruszek czy śliwek. Po odkryciu trzciny cukrowej przez Persów i rozprzestrzenieniu się jej upraw na całym Środkowym Wschodzie w składzie przysmaków znalazła się tzw. biała sól'1, tj. cukier, który tak nazywano w średniowieczu, a sprowadzano go do Europy Środkowej i krajów słowiańskich przez Wenecję od końca pierwszego tysiąclecia. Z uwagi na drogi proces jego pozyskiwania wyroby cukiernicze miały charakter luksusowy i zarezerwowane były dla władców oraz bywalców ich dworów. W XVI stuleciu na stoły europejskich możnowładców dotarły nasiona kakaowca, które dały początek wszechobecnej dziś czekoladzie. Sądzi się, że dziełem mediolańczyków są marcepan i bezy, być może drażetki zawdzięczamy Juliusowi Dragatusowi z rodu Fabiusów, który rozdawał je mieszkańcom Rzymu z okazji urodzin i zamążpójścia, a cukierki w postaci pastylek cukiernikowi Medyceuszy, zwanemu Giovannim Pastillą (Toussant-Samat, 2002, s. 508-520).

Słodycze wkroczyły pod strzechy po okresie rewolucji przemysłowej i upowszechnieniu się produkcji cukru z buraka. Pojawiły się wata cukrowa, żelki, toffi, lizaki, gumy do żucia (Toussant-Samat, 2002, s. 513-514). Dziś może ich

${ }^{1}$ Sól (morska i kamienna) nie była wówczas poddawana rafinacji, dlatego miała barwę szarą (Toussaint-Samat, 2002, s. 496). 
spróbować każdy, nie tylko osoba wyjątkowo zamożna. I chociaż współcześni producenci przysmaków — podobnie jak ci z przeszłości — prześcigają się w wymyślaniu nowych receptur, smaków i kształtów, to z powodu demonopolizacji muszą zwracać większą uwagę także na opakowanie swoich wyrobów i pojawiające się na nich nazwy własne. Upowszechnienie rynku słodyczy przerodziło się w walkę o klienta, którego wszyscy producenci próbują zwabić także etykietą, przywiązać na stałe do swojej marki. Wagi nabrała zatem nazwa własna określonego produktu, ponieważ jest on wytwarzany przez konkurujących ze sobą producentów.

We współczesnej kulturze obrazkowej, zwanej okulocentryczną, znaczenie ma także sama etykieta, jej kolor, faktura, kształt czy ilustracja towarzysząca nazwie, stanowiąca nie tylko tło, lecz także ją niejednokrotnie dopowiadająca lub odzwierciedlająca. Najbardziej jednak widoczna na opakowaniu jest niezmiennie nazwa własna, której postać z uwagi na jego niewielką strukturę jest specyficzna. Musi być ona przede wszystkim prosta, łatwa do wymówienia, adekwatna, wpadająca w ucho, a zarazem ponadczasowa, oryginalna i wywołująca pozytywne skojarzenia (Rutkowski, 2003, s. 243; Rutkiewicz-Hanczewska, 2019, s. 401).

Kreowana z największą starannością za pośrednictwem specjalistycznych firm brandingowych nazwa pełni funkcję komunikatu, nie jest tylko ozdobnikiem. Jej rola polega na informowaniu, na swoiście pojmowanym ,uwodzeniu” klienta (Rutkowski, 2003, s. 243). Wobec powyższego należy ją traktować jako pełnoprawny tekst, który ma swoje ograniczenia jedynie w zakresie długości. Poza tym rządzi się tymi samymi prawami, jakie odpowiadają innym znanym nam tekstom, np. literackim. Tekst nazewniczy jako twór minimalny (Rutkiewicz-Hanczewska, 2013), wyjątkowo zsyntetyzowany (Rutkowski, 2003, s. 243), musi wyraźnie i esencjonalnie odwoływać się do wyobraźni konsumenta, jego podświadomości, raz do emocji, innym razem do racjonalizmu, co uzależnione jest w dużej mierze od typu nazywanego produktu oraz kupującego (Rutkiewicz-Hanczewska, 2007).

Tak pojmowana nazwa własna produktu bazuje zwykle na sile językowego obrazowania (Rutkowski, 2003, s. 243), którą dają jej bądź inne minimalne teksty, czyli nazwy własne (nazwy odproprialne), bądź rzeczowniki pospolite, z jednej strony, angażujące emocje, a z drugiej — mówiące wprost do odbiorcy, informujące o walorach kupowanego wyrobu (nazwy odapelatywne). W tej grupie nazw doskonale mieszczą się określenia słodyczy: cukierków, drażetek, pralin, batonów, czekolad, lizaków, wafli, pianek, galaretek, o których będzie mowa w artykule w ujęciu porównawczym, tj. w nawiązaniu nie tylko do przestrzeni polskiej, lecz także ukraińskiej². Obie wymienione kultury należą do słowiańskich, ale różni je

${ }^{2}$ Część nazw ukraińskich słodyczy wynotowano z pracy licencjackiej pt. „Polskie i ukraińskie nazwy słodyczy", którą Diana Bylyna przygotowała pod moim kierunkiem. Pozostałe nazwy ukraińskich produktów cukierniczych oraz polskie nazwy słodyczy wyekscerpowano ze stron internetowych najważniejszych producentów tej grupy wyrobów oraz sklepów ze słodyczami. Analizowany zbiór 
obecna sytuacja społeczno-gospodarczo-polityczna. Ukraina stała się państwem niepodległym w 1991 roku. W przeciwieństwie do Polski ma nieustabilizowaną sytuację polityczną, a od czasu aneksji Krymu przez Rosję w 2014 roku jest w konflikcie z Federacją Rosyjską, w stanie wojny określanej jako hybrydowa (Stępniewski, 2016, s. 45-46; Pawlak, 2017, s. 268-273). W przeszłości stanowiła część Związku Socjalistycznych Republik Radzieckich, który oficjalnie przestał istnieć w 1991 roku (Serczyk, 2009, s. 377-378), czego pokłosie jest widoczne w niejednoznacznym stosunku Ukraińców, zwolenników starego systemu, do współczesnej Rosji. Znaczna część mieszanego etnicznie społeczeństwa mówi po rosyjsku, chociaż status języka urzędowego przysługuje językowi ukraińskiemu (Serczyk, 2009, s. 381; Pawlak, 2017, s. 285). W zasadzie można powiedzieć, że Ukraina jest państwem ,nieoficjalnie dwujęzycznym” (Olszański, 2012, s. 6), a około 16-18\% mieszkańców posługuje się surżykiem, czyli formą komunikacji, w której dominuje ukraiński z licznymi wpływami języka rosyjskiego, wynikającymi z długoletniej koegzystencji tych dwu języków (Olszański, 2012, s. 12; Wochelski, 2020, s. 72-73).

Określenia słodyczy reprezentują gatunek chrematonimów, tj. nazw handlowych. Ten segment rynku i związane z nim produkty opisywano w Polsce w kontekście wszystkich nazw marketingowych (Gałkowski, 2008, s. 95, 311; Rutkiewicz-Hanczewska, 2013, s. 151, 220, 263-265, 288, 313, 316, 326). Osobne opracowania poświęcono zbliżonym produktom, tj. nazwom herbat (Magda-Czekaj, 2011), drinków (Lech-Kirstein, 2011) i soków (Tomecka-Mirek, 2010). O technikach motywacyjnych nazw wyrobów piekarniczych i cukierniczych pisała również Violetta Jaros (2011). Badaczka omówiła sposoby tworzenia nazw takich produktów, jak: bułki, chleby, ciasta, torty. Również w badaniach ukraińskich o nazwach producentów słodyczy i ich wyrobów wspomina się przy okazji opisu mechanizmów tworzenia określeń firm usługowo-handlowych (Lučik, 2003, s. 391-393; Yermolenko, Zymovets', 2018, s. 111). Odrębnych opracowań doczekała się grupa onimów, które określa się terminem чоконіми. To określenia wyrobów czekoladowych i cukierków, które zostały przeanalizowane pod względem leksykalno-semantycznym (Kalenûk, Voronûk, 2018, s. 169-171) oraz w kontekście semiotyki (Želâzkova, 2019, s. 100-103).

Przedmiotem niniejszego artykułu będą określenia słodyczy (rodzimej produkcji ${ }^{3}$ ) formowane $\mathrm{w}$ dwu przestrzeniach narodowych, za pomocą których buduje się wizerunek denotatu. Ich charakterystyka stanowi główny cel opisu, mający ujawnić językowe parametry kreacji potencjalnych produktów, należących do

onimów z uwagi na istnienie nie tylko marek głównych, lecz także licznych submarek i submarek bis nie ma charakteru zamkniętego.

${ }^{3}$ Wyjątkowo w materiale znajdą się nazwy produktów firm z obcym kapitałem, lecz tworzone tylko dla odbiorcy rodzimego, np. Krakuski firmy Bahlsen. 
różnych kultur. W wypadku nazw marketingowych, reprezentujących typ tekstów perswazyjnych, uwaga kreatorów skupiona jest na referencie, na jego wyobrażeniu. W zasadzie to właściwości obiektu decydują o tym, jaką nazwą będzie on oznaczany (Rutkiewicz-Hanczewska, 2013, s. 262). Twórca nazwy produktu spożywczego chce go widzieć w określony sposób, a przynajmniej wydaje mu się, że odczytuje preferencje kulinarne jego odbiorcy. Tak skonstruowana nazwa z założenia znaczy, sugeruje związek motywacyjny między nią a nazywanym obiektem (Rutkowski, 2003, s. 243-244; Rutkiewicz-Hanczewska, 2013, s. 215 220), a zarazem stawia odbiorcę „w obliczu pewnej wizji, obrazu świata czy też nowego, lepszego życia" (Rutkowski, 2003, s. 244). Dlatego pośrednio w artykule opisowi zostanie poddany również odbiorca, do którego kierowane są komunikaty nazewnicze producentów. On implicytnie wyznacza zastosowane strategie językowe, które w założeniu twórców nazw mają na tyle uatrakcyjnić produkt, by został przez niego kupiony, a następnie by jego nazwa została na stałe włączona w proces decyzyjny powtarzających się wyborów konsumenckich.

\section{STRUKTURA TEKSTU MARKETINGOWEGO: MARKA, SUBMARKA, SUBMARKA BIS, DESKRYPCJA}

Opis nazw marketingowych nie należy do najłatwiejszych z uwagi na ich heterogeniczną i wielopoziomową strukturę, niepozwalającą na jednoznaczne stwierdzenie, który z jej elementów stanowi nazwę własną. Taka struktura oczywiście nie ułatwia ich charakterystyki, ale też nie czyni jej niemożliwą. Tworzyć ją może zarówno marka główna (rodzinna, nazwa matka, house brand), jak i marka poboczna (indywidualna, submarka).
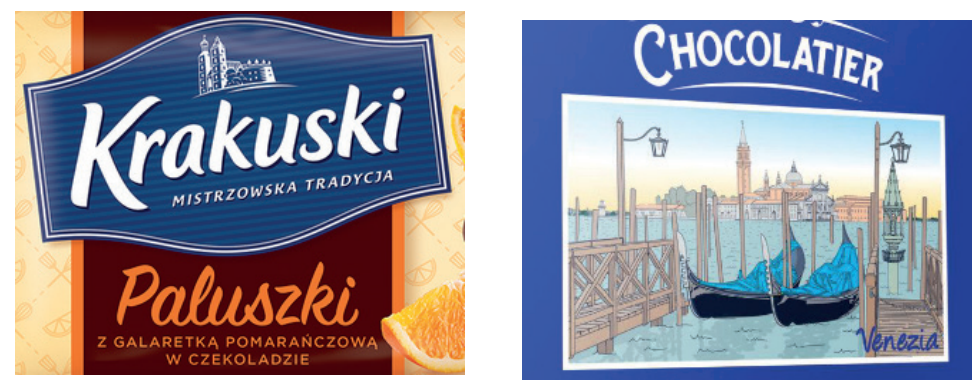

Rys. 1. Przykład monotekstu (po lewej: na opakowaniu submarka Krakuski, brak marki głównej Bahlsen; po prawej: na opakowaniu submarka Chocolatier, brak marki głównej Millennium).

W zależności od przyjętej przez firmę strategii teksty nazewnicze zamieszczone na etykiecie produktu przyjmują postać submarki (monoteksty, zob. fot. 1) lub 
marki matki (megateksty, zob. fot. 2). Wówczas jednak wielopoziomowość jest budowana w dalszym ciągu, i tak np. w monotekstach obok submarki Krakuski pojawić się mogą dodatkowe submarki bis, typu: Barbakanki, Deserowe, Duelki, Florianki, Krystynki, Maltanki, Serduszka, Śmietankowe, Zbożowe. W ukraińskiej przestrzeni brandingowej submarce Chocolatier towarzyszą nazwy z niższego poziomu: Verona, Venezia, Assorted. Podobnie w otoczeniu megatekstu (marki głównej) Verbena wystąpić mogą dodatkowe teksty w rodzaju: Lawenda, Dzika róża, Melisa itd., przypominające deskrypcje obecne w strukturze linktekstów.

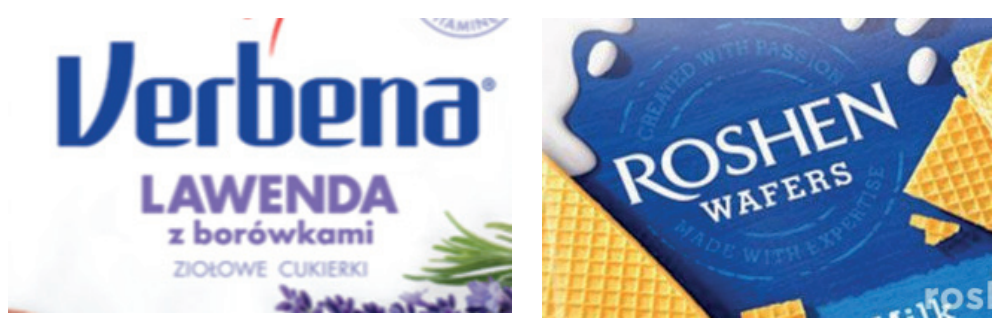

Rys. 2. Przykład megatekstu (na opakowaniu marka główna: po lewej polska Verbena, po prawej ukraiński Roshen).

Najpopularniejsze są produkty oznaczane dwoma rodzajami marek, spośród których dominująca jest submarka (to tzw. linkteksty, zob. fot. 3). Bardzo rzadko marka główna i submarka są tak samo istotne (to tzw. duoteksty).
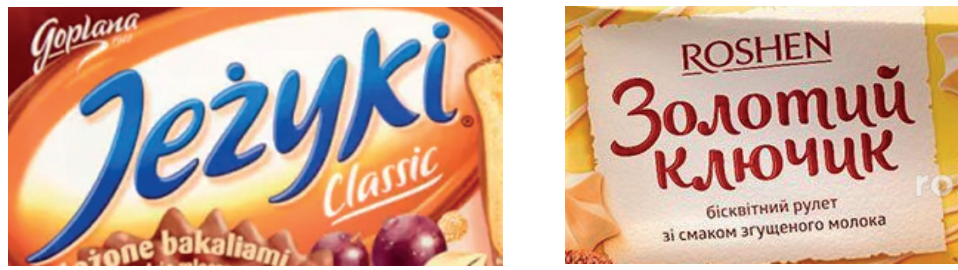

Rys. 3. Przykład linktekstu (na opakowaniu po lewej dominuje submarka Jeżyki, marka główna Goplana jest w tle, po prawej dominuje submarka Золотий Ключик, marka główna Roshen w tle).

W artykule oglądowi poddane zostaną zarówno marki matki, jak i submarki (również submarki bis). Dodatkowe dookreślenia submarki (tzw. deskrypcje, Laforet, Saunders, 1994, s. 67) będą brane pod uwagę tylko w wyjątkowych sytuacjach, chociaż stanowią one część specyficznego, bo wielopoziomowego tekstu marketingowego, który pełni odmienne w stosunku do dwu wymienionych jego typów funkcje, polegające na gatunkowym opisie denotatu, swoistym tłumaczeniu nazwy markowej: ziolowe cukierki (Verbena), herbatniki z platkami owsianymi 
(Krakuski), toff mleczne z kremem śmietankowym (Toffino marki Goplana). Zgodnie z tym, co powiedziano wyżej, pominięte zostanie dookreślenie kokosowo-orzechowe, towarzyszące głównej marce Wawel i submarce Tiki Taki oraz podtytuł Galaretki o smaku owocowym w czekoladzie pojawiający się pod nazwą Opolanki marki Odra, a z opakowania pierników firmy Skawa do analizy wykorzystana zostanie nazwa, którą producent wyróżnił graficznie - Pierniczki Baśniowe (fot. 4). Fragment $w$ czekoladzie z nadzieniem jabtkowym oraz jego angielski odpowiednik, zamieszczony pod wersją polskojęzyczną, nie będzie rozpatrywany w artykule.

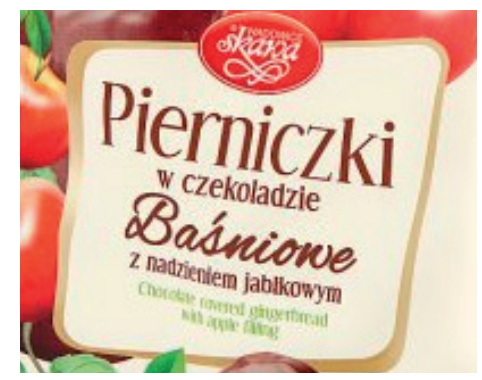

Rys. 4. Jeden z typów złożonej struktury nazewniczej słodyczy.

Jak zatem za pośrednictwem nazw słodyczy można dokonać kreacji tego typu obiektów? Jakie wyobrażenie denotatu tworzą i jakie ono jest w ostateczności, a pośrednio - kim jest ich odbiorca, ponieważ charakteryzowane marki zostały stworzone z myślą, by go uwieść. Czy w tych kreacjach można dostrzec podobieństwa i różnice pomiędzy nazwami tworzonymi w Polsce i na Ukrainie?

\section{KOMUNIKAT NAZEWNICZY I ADRESAT}

To, co zwraca uwagę badacza onomasty analizującego określenia słodyczy, to wyraźna obecność innych rzeczowników własnych w ich strukturze, można powiedzieć — nazw z przeszłością, nieprzezroczystych. Dzięki nim twórcy polskich chrematonimów patrzą na potencjalnego adresata jak na osobę, która ceni tradycję, regionalność i wysoką jakość produktu. Rzadziej wykorzystują do tego odapelatywne określenia typu: Regionalne (herbatniki firmy Cukry Nyskie), Czekoladki $z$ Klasa (firmy Solidarność). Mają one bowiem charakter jedynie deskrypcji, której trzeba zawierzyć a priori. Mniej bezpośrednie odapelatywne asocjacje z nazwą określonego regionu tworzą nazwy Szkloki oraz Kopalnioki (submarki śląskie). U ich podstaw znajdują się śląskie wyrazy szklok 'cukierek typu landrynka' (: szkło) i kopalniok 'cukierek o czarnym kolorze' (: kopalnia). Pierwszy rodzaj cukierków to landrynki. Drugi ma postać grudek węgla i jest sprzedawany w pudełku 
przypominającym wózek górniczy na węgiel. Ponieważ jednak konsumenta trzeba przekonać jednogłośnie, producenci chętnie sięgają w procesie kreacji nazw do innych rzeczowników własnych, które w swoim zakresie znaczeniowym niosą już sprawdzoną obietnicę sukcesu. Zgodnie z tym modelem kreowano zarówno nazwy powstające w przeszłości (np. Cukry Nyskie, Odra, Wista), jak i kreuje się określenia najnowsze (np. Koszalińska Pracownia Słodyczy „Karmelek”, Krakuski). Przedsiębiorcy wyjątkowo często podkreślają regionalizm swoich wyrobów, sięgając po nazwy różnych miast polskich (Krakuski, Koszalińska Pracownia, Likworki Gdańskie, Mieszanka Toruńska, Miętowe Lubelskie, Serca Toruńskie, Śliwka Nałęczowska, Wadowickie, Warszawianki), regionów geograficznych (Beskidzkie, Pomorzanka, Śląkie), urbanonimów (Barbakanki, Wawel) oraz hydronimów (Odra, Olza, Skawa, Wisła). Obcojęzyczne odwołania także się pojawiają, lecz mają charakter sporadycznych sygnałów: Amerykanki, Fiji (batony marki Wolność), Malaga, Wafle Mexico.

Nieco inaczej prezentują się nazwy słodyczy ukraińskich. Określenia cukierków w tym kręgu kulturowym zdecydowanie częściej nawiązują do egzonimów, w tym do nazw znanych światowych stolic (Florens, Віденська, Milan Richtown, Празька, Rome Richtown, Venice Richtown, Cnapma, Sorrento, Tokio, Varsovia, Venezia, Veron), a także innych nazw geograficznych (Баварськi, Mont Blanc, Tenerife) czy określeń mitologicznych (Аркадія). Chociaż odwołania lokalne też występują w funkcji nazw ukraińskich słodyczy i ich wyrobów, to są jednak w mniejszości: Артек (od nazwy znanego obozu pionierskiego na Krymie, obecnie przeniesionego na zachód Ukrainy), Вечірній Київ (czekoladki marki Roshen), Lvivsky дефіляди (krówki marki Світоч w oryginalnej mieszanej pisowni), Стріла Подільська (od nazwy Поділля = Podole), Слобожанщина (od nazwy historycznego regionu wschodniej Ukrainy, okolic Charkowa, zwanej gubernią słobodzko-ukraińską, Ukrainą Słobodzką), Запорiзькi (od nazwy miasta Запоріжжя = Zaporoże, pierniki firmy Хлібодар), Житомирські ласощі (od nazwy miasta Житомир = Żytomierz).

Lokalność i tradycja ujawnia się również w pozostałych, tj. antroponimicznych nawiązaniach intertekstualnych. U podstaw polskich nazw marketingowych występują głównie imiona żeńskie, rzadziej męskie (por. Idzikowska, 2000, s. 214-215): Danusia, Grześki, Haneczki, Katarzynki, Maja, Michatki, Mieszko, Pawetek, Wojtek. W tej grupie niewiele jest antroponimów spoza polskiej kultury: Carla (bombonierka marki Wisła), Dicki (cukierki marki Wolność), w przeciwieństwie do ukraińskich nazw cukierków, wśród których popularniejsze okazują

${ }^{4}$ Poza motywacją od imienia Dick (: Richard) możliwa jest również odapelatywna interpretacja tej nazwy (od słowa dick oznaczającego w języku angielskim wulgarne określenie męskiego członka), która stała się przyczyną renominacji marki Dick Black na Bick Black w latach 90. XX wieku. (Rutkowski, 2003, s. 248). 
się te z obcego kręgu kulturowego (Амелія, Артемон, Charlie, Esmeralda, Jillian, Karolina, Мирель, Наполеон, Ніколь, Oscar Le Grand, Супер-Джек, Жемчужина Клеопатры 'perła Kleopatry', Scarlet), w tym z mitologii (Прометей), rzadziej rodzime (Оленка, от Маруси).

W Polsce i na Ukrainie popularnością cieszą się także nazwy motywowane nazwiskami. Fundują one przede wszystkim określenia firm cukierniczych: Dobosz, Kopernik, Wedel, Mateo (od imienia i nazwiska właścicielki firmy Marzeny Tkaczuk), Tago (od imienia i nazwiska właściciela firmy Tadeusza Gołębiewskiego), bardzo rzadko samych produktów. Wówczas są to nawiązania do znanych nierodzimych nazwisk w rodzaju Valentino (praliny firmy Kopernik). Tego rodzaju asocjacje spotyka się również w nazwach produktów ukraińskich. Jedna z najsłynniejszych współczesnych marek Roshen (czyt. roszen) pochodzi od nazwiska właściciela fabryki, byłego prezydenta Ukrainy — Petra Poroszenki. Istniejąca od 1991 roku kijowska firma $A B K(A V K)$ nosi nazwę składającą się z inicjałów nazwisk i imion głównych współudziałowców spółki (zob. Володимир Федорович Авраменко oraz Валерій Кравець). Nazwiska pojawiają się również w ukraińskich submarkach typu Johnny Krocker (cukierki firmy Roshen, por. nazwisko brytyjskiego generała Johna Crockera).

Imiona bohaterów literackich i filmowych także wykorzystuje się w funkcji nazw słodyczy, przy czym w polskim materiale tych motywacji jest niewiele: Goplana (marka główna), M jak Miłość, Wafelki Ojca Mateusza, Gucio (firmy Wolność). Jeszcze rzadsze są motywacje muzyczne: Makarena (galaretki firmy Pomorzanka) czy Scherzo (firmy Kopernik), chociaż ostatnią nazwę można potraktować jako odapelatywną. Na pochodzenie odproprialne wskazuje informacja o dołączonej do opakowania płycie CD z muzyką Chopina i fragmentem jego listu o toruńskich piernikach. Wspomniane motywacje nazewnicze nie są niczym wyjątkowym. Symbole narodowe i literackie wykorzystywali również twórcy nazw wódek (Chopin i Pan Tadeusz) czy papierosów (Jan III Sobieski). Sięganie do panteonu narodowego ma za zadanie konotować najwyższą jakość produktu, jego „narodowy” charakter (Rutkowski, 2003, s. 246). Za pierwowzór takich nazw uznać można określenie poznańskiej fabryki — Goplana, która powstała w 1913 roku. Wówczas (w okresie przed odzyskaniem niepodległości) nazwy o podobnym źródłosłowie miały podkreślać polskość produktów, ich związek z regionem, a także dbać o przychylność potencjalnych inwestorów. Ten sam typ motywacyjny pod względem uwikłania polityczno-społeczno-kulturowego mają odtoponimiczne określenia firm cukierniczych z początku XX wieku: Wawel, Wisła, Olza.

Szczególnie chętnie po nazwy literackie sięgają producenci ukraińscy $^{5}$ (Yermolenko, Zymovets', 2018, s. 111; Kalenûk, Voronûk, 2018, s. 171).

${ }_{5}^{5}$ To druga co do popularności grupa motywacyjna wśród ukraińskich nazw wyrobów czekoladowych i cukierków (Kalenûk, Voronûk, 2018, s. 170-171). 
W nazwach ich produktów znajdują się liczne nawiązania do takich tytułów utworów literackich i muzycznych, jak Наталка Полтавка (tytuł dramatu znanego ukraińskiego poety i dramatopisarza z przełomu XVIII i XIX stulecia Iwana Kotlarewskiego), Лісова пісня (tytuł dramatu-feerii klasyka literatury ukraińskiej z przełomu XIX i XX stulecia, ukraińskiej poetki i pisarki — Łesi Ukrainki), Пиковая дама (tytuł powieści Aleksandra Puszkina), Алеко (postać ze sztuki Cyganie Aleksandra Puszkina, tytuł opery rosyjskiego kompozytora Siergieja Rachmaninowa z librettem do sztuki Puszkina), Сказки Пушкина (wybitnego rosyjskiego pisarza) oraz Венеціанська ніч (tytuł pieśni gondolierów, którą stworzył w czasie podróży do Włoch rosyjski kompozytor z XIX stulecia - Michał Glinka). W porównaniu z nazwami polskimi również wyjątkowe miejsce w chrematonimii ukraińskiej zajmują określenia motywowane nazwami filmów animowanych dla dzieci (por. Kalenûk, Voronûk, 2018, s. 170): Мама и Медведь, Курочка Ряба, Веселі гуси (tytuł piosenki dla dzieci), Золотое яичко, Умка. Те̨ grupę dopełniają także tytuły lub imiona bohaterów bajek zachodnich: Гулівер, Ocean Story (tytuł książki The Ocean Story) і Шрек. W materiale polskim można wskazać zbliżoną motywacyjnie nazwę marki głównej Śnieżka (bohaterki bajki braci Grimm „Królewna Śnieżka”).

Wrażenie najwyższej jakości, a przede wszystkim oryginalności produktów budują nazwy o wyjątkowo silnym intertekstualnie charakterze, a mianowicie określenia nawiązujące do nazwy marki głównej: Tagotki $(\leftarrow$ Tago), Pomożelki

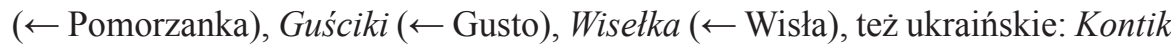
( $\leftarrow$ Konti), Roshetto $(\leftarrow$ Roshen). Drugą ich grupę tworzą nazwy typu: Wedlove, Mieszanka Wedlowska $(\leftarrow$ Wedel), Michatki Śnieżkowe ( $\leftarrow$ Śnieżka), a także synonimiczne określenia wobec wcześniej wymienionych w formie wyrażenia przyimkowego (Michatki z Wawelu; Michatki z Hanki; Michatki z Siemianowic). Owe nawiązania regionalne są niekiedy wymuszone sytuacją rynkową i silną walką o klienta, zwłaszcza jeśli kilku producentów chce być właścicielem określonej marki, a ona ma ugruntowane już miejsce w świadomości kupujących, jak na przykład słynne Michałki. Do ich produkcji i wykorzystania marki ma prawo tylko firma Śnieżka-Invest, która wypromowała też synonimiczne nazwy tego samego produktu: Michałki z Hanki, Michałki Śnieżkowe (firmy Śnieżka). Kolejne przedsiębiorstwa wprowadziły na rynek zmodyfikowane określenia dyferencjujące. Cześć z nich również wskazuje na związki z określonym regionem, jedne bardziej, drugie mniej bezpośrednio: Michatki z Siemianowic (firmy HANKA-INVEST), Piastowskie Michałki (firmy Odra), Michatki Zamkowe (firmy Wawel). U podstaw innych nazw znajdują się typowe człony właściwe produktom cukierniczym lub modyfikacje formy bazowej: Złote Michatki (firmy Solidarność), Cukierek Michałkowy (firmy Wolność), Leśne Michaśki (firmy Dobosz), Michaśki (firmy Pszczółka), Michaszki (firmy Mieszko). 
Mniej nazw odchrematonimicznych znaleźć można w nazewnictwie ukraińskich słodyczy. Mają one podwójną motywację. Dla przykładu: określenie Maк Житомирський nawiązuje do nazwy geograficznej lub do określenia zakładu produkcyjnego Житомирські ласощі.

W kontekście onimów ukraińskich zwraca uwagę ich pisownia. W liternictwie bowiem pojawia się stosunkowo często alfabet łaciński zamiast współczesnego alfabetu ukraińskiego, co wynika ze strategii producentów rozszerzających swoje rynki zbytu o odbiorcę zachodniego. Także nazwy marki głównej na rynku rodzimym zapisywane po ukraińsku lub rosyjsku podlegają — wbrew opinii o nieprzetłumaczalności nazw - translacji na język angielski lub transpozycji (transliteracji), np. ABK - AVK, Стимул - Stimul Sweet, Бисквит-Шоколад — BiscuitChocolate. Wynika to częściowo ze specyfiki adresów internetowych, a dokładnie — domen konkretnych firm (por. stimulsweet.com), które mają nazwy zapisane alfabetem łacińskim (por. Lučik, 2003, s. 393).

Warto podkreślić, że część ukraińskich nazw słodyczy występuje również w języku rosyjskim. Tak oznaczone produkty eksportuje się zapewne na rynki wschodnie, zwłaszcza do Federacji Rosyjskiej. W ten sposób nazywa swoje produkty firma Бисквит-Шоколад z siedzibą w Charkowie (wcześniej w Petersburgu). Dla przykładu, na stronie producenta (https://biscuit.com.ua) na opakowaniu czekoladowych cukierków pojawia się nazwa rosyjska Грильяж восточный, a pod ilustracją produktu znajduje się nazwa po ukraińsku Грильяж східний lub angielsku Oriental Crocant. To jedno ze zjawisk odzwierciedlających tzw. „problem językowy" (Olszański, 2012, s. 5) na Ukrainie, wynikający z dwujęzyczności jej mieszkańców (będącej skutkiem długoletniej zależności od Rosji), chociaż w konstytucji z 1996 roku jedynym językiem narodowym i urzędowym jest ukraiński' . Oba języki przenikają się również na samych etykietach słodyczy. Producenci stosują je wymiennie, tj. submarkę zapisują po ukraińsku, a deskrypcję po rosyjsku, lub submarkę po rosyjsku, a deskrypcję po ukraińsku (np. w wypadku marki Золотий ключик), bądź równolegle: na opakowaniach cukierków pojawiają się wszystkie nazwy w obu językach (np. cukierki firmy Бисквит-Шоколад z napisem po rosyjsku Николь z deskrypсjа̨ конфеть оraz po ukraińsku Ніколь z deskrypcją иукерки). Zdaniem badaczy ów problem językowy Ukrainy (Olszański, 2012, s. 6) można rozwiązać na kilka sposobów: 1) tolerując stan ,nieoficjalnej dwujęzyczności”, 2) legalizując język rosyjski w życiu publicznym i uznając go ostatecznie za równorzędny język państwowy bądź 3) usuwając go konsekwentnie z życia publicznego. Polityka językowa, którą widać w przestrzeni marketingowo-brandingowej wskazuje na to, że producenci biorą pod uwagę pierwsze z rozwiązań,

${ }^{6}$ Język ukraiński przed XIX wieku był traktowany jako dialekt języka rosyjskiego. Próba zapisu języka ukraińskiego pochodzi z 1837 roku (Wochelski, 2020, s. 73). Por. Kosmeda (2019). 
chociaż trudno powiedzieć, czy drugie z nich jest bezsprzecznie odrzucane oraz czy władze państwowe mają nad tym kontrolę i w jakim zakresie.

Ważne w kontekście sytuacji politycznej Ukrainy jest także tłumaczenie nazw rosyjskich na język ukraiński, rzadziej angielski (np. cukierki Crabs to dawne Рачки oraz Рачок). Mowa o określeniach cukierków, które były bardzo popularne w czasach przynależności kraju do ZSRR, a zatem o utrwalonych w mentalności konsumentów markach. Wielu producentów ma je w swoim asortymencie, wyraźnie nawiązuje też do ich dawniejszej szaty graficznej (zob. fot. 5). Mowa o nazwach w rodzaju Білочка, Кара-кум, Оленка (ros. Алёнка), Ромашка, Чайка, Червоний мак, firmy Roshen czy Гулівер (ros. Гулливер) firmy ABK. Ich obecność na rynku wynika z przywiązania do tradycji, a nawet sentymentu, tęsknoty do czasów dzieciństwa i jednej z ówczesnych rozrywek, polegających na kolekcjonowaniu opakowań z charakterystycznymi ilustracjami na cukierkach i czekoladach.

Produkcją tradycyjnych marek z czasów ZSRR zajmują się firmy z różnych obszarów Ukrainy, zarówno z zachodu (Roshen, ABK), jak i wschodu (Millennium). Dla przykładu: ta ostatnia produkuje wyroby oznaczane zarówno nazwami anglojęzycznymi (Riviera, Ocean Story, Green Tea, Mousse, Elegance), jak i ukraińskimi. Produkcją marek z czasów Związku Radzieckiego (Білочка, Ведмедик у лісі, Кара-кум, Московские) zajmuje się jedna z jej podmarek Золотий запас. Wobec powyższego popularność dawnych nazw marketingowych nie wiąże się ściśle z geografią. W takim samym stopniu stanowią one symbol dzieciństwa dla mieszkańców zarówno zachodniej, jak i wschodniej Ukrainy, chociaż firmy zlokalizowane we wschodniej Ukrainie oznaczają swoje produkty w języku rosyjskim częściej.
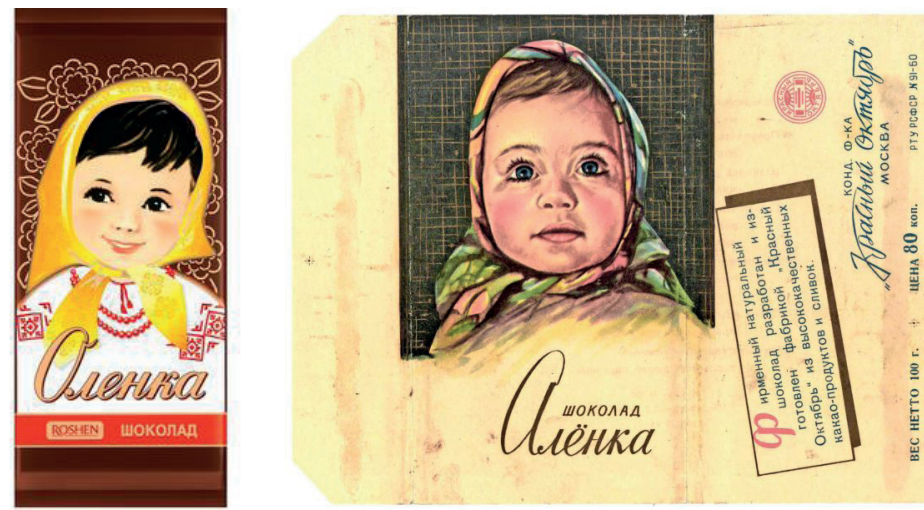

Rys. 5. Nazwy tradycyjnych słodyczy; po lewej — produkowanych obecnie przez firmę Roshen pod nazwą Оленка, po prawej — z czasów ZSRR pod nazwą Алёнка. 
Regionalizm i tradycja z punktu widzenia konsumenta są istotne według twórców nazw w procesie nazywania słodyczy w obu kulturach. Postać odbiorcy produktu silnie oddziałuje na jego strukturę nazewniczą, jest w nią implicite wpisana, a czasem objawia się także explicite. W gronie odbiorców słodyczy znajdują się wszystkie grupy wiekowe: dzieci, dorośli, osoby starsze. Te informacje występują na opakowaniach okazjonalnych, zwłaszcza dotyczących jednego rodzaju produktu: Krówki Dla Kochanej Babci, Krówki Kochanym Dziadkom, Krówki Najlepsza Babcia na świecie, Krówki Najlepszy Dziadek na świecie; Бабусині байки. Spośród adresatów dorosłych wyróżnienia dotyczą dwu grup społecznych: rodziny (Duetka Familijna, Familijne), studentów (Przysmak Studencki) oraz wielbicieli sportu: Przysmak Kibica, Mieszanka Kibica, Lewy Sierpowy, Sztanga; Ole! Ole!, Футбол, Скейт. Jeśli chodzi o dzieci, wskazania bezpośrednie — w rodzaju: Michaszki Junior czy Любимов Kids (submarka Любимов) należą do rzadkości. Częściej ten adresat charakteryzowany jest za pomocą nazw zdrobniałych utworzonych zarówno od propriów (polskie: Barbakanki, Grześki, Haneczki, Krakuski, Florianki, Maltanki, Tagotki, Warszawianki, Wisetka, Sofijka, Jogusie, ukraińskie: Марциианчик), jak i apelatywów (Duelki, Eliteski), także wykrzyknień (polskie: $A k u k u$, ukraińskie: $W O W$ ) lub wyrażeń dźwiękonaśladowczych (ukraińskie: Бім-Бом, Кo-Ko Choco, My-y-y). Zwykle też jako ilustracje na opakowaniach dla dzieci pojawiają się różne postaci często wymyślonych bohaterów, np. w Polsce Hibbi (słodycze z hipopotamem na opakowaniu), na Ukrainie TIMI (słodycze z misiem w stroju Supermana na opakowaniu).

Oznaczenie pory i miejsca to kolejny składnik komunikatu, jaki przekazują charakteryzowane teksty nazewnicze. Polskie i ukraińskie nazwy najczęściej wskazują na szeroko rozumiany czas, moment spożycia określonych słodyczy (polskie: Deserowe, Koktajlowe, Caramel Break, Wiosenne; ukraińskie Bonjour oraz День $i$ нiч), chwile (ukraińskie: Moments), święta, uroczystości i podróże (polskie: After Party, Mieszanka Imieninowa, Piknikowe; ukraińskie: Cocoa Travel) oraz miejsca (Domowe, Leśne, Kulki Teatralne). Wyróżniają się na tym tle określenia ukraińskie, które chętnie odwołują się do pory nосnеj: Венеціанська ніч, Київ вечірній, Оксамитова ніч, Південна ніч, Шоколадна ніч, Таинственная ночь. Вус́ może stanowią one nawiązanie do ideonimu Венеціанська ніч (autorstwa Michaiła Glinki). Niezmiennie w obu kulturach kreatorzy nazw najczęściej sięgają do określeń uczuć i emocji: polskie: L'Amour, Całusy (czekolada w kształcie ust firmy Wawel), Całuski (pierniki lukrowane z nadzieniem o smaku śliwkowym firmy Kopernik), Cmok (lizaki firmy Bałtyk), Od serca, Serca Toruńskie, Serca w czekoladzie (pierniki firmy Kopernik), Sympatie, Ulubiona czekolada, Wedlove (biszkopty z galaretką w czekoladzie, por. ang. love); ukraińskie: Amor, Amour, Kiss, Love, Любимов, Sweet Heart, Ti ато, Only уои, Солодкі почуття (słodkie uczucie), Самой любимой. Daje się je bowiem wówczas w prezencie jako symbol wyrażanego uczucia. 


\section{KOMUNIKAT NAZEWNICZY I DENOTAT}

Nazwy słodyczy budują nie tylko obraz tradycyjnego, oryginalnego, bo regionalnego wyrobu, powiązanego z konkretnym miejscem produkcji i ściśle określonym symbolem narodowym, $\mathrm{z}$ jego adresatem osadzonym $\mathrm{w}$ konkretnym czasie i miejscu, lecz także za ich pośrednictwem polscy i ukraińscy producenci wskazują na właściwości słodyczy, skupiają uwagę na produkcie, zarówno na jego stronie wewnętrznej, jak i zewnętrznej. Ten obraz jest wyjątkowo wszechstronnie zaprezentowany. Dotyczy w zasadzie wszystkich właściwości produktu spożywczego: smaku, składu, kształtu oraz koloru.

Niezależnie od narodowości poza określeniami intertekstualnymi producenci równie chętnie tworzą nazwy w pełni metatekstualne, począwszy od wskazania na gatunek samego wyrobu: Bonbony, Bon Bon, Bombonita, MonBon, Karmelek, Kopalnioki, Landryny, Draże, Sękacz (polskie), Szkloki; Батончик, ChocoLapki, Candy Nut, LolliPops (lizaki od ang. lollipop), Fudgenta (ukraińskie). Rzadziej te wydawałoby się, mało atrakcyjne, bo transparentne — struktury próbują graficznie uatrakcyjnić w rodzaju: CIA? CHA! (pierniki firmy Kopernik). Wyjątkowo popularne są określenia informujące o składzie danego produktu, co wynika z urozmaicania wyrobów tej samej linii produkcyjnej, prześcigania się firm w walce o klienta, tworzenia nowych, oryginalnych propozycji (por. Kalenûk, Voronûk, 2018, s. 170). W nazwach pojawiają się informacje o owocach i roślinach w recepturze: Bananowy Raj, Kokosowy Raj, Szok owocowy, Baton Marcepanowy, Kakaowe, Marcepanki, Śliwka Książeca, Kakaowe, Cherissimo (od ang. cherry 'wiśnia'), Złoty Orzech, Eukaliptus, Irysy z makiem, Kwaśny Shock, Kwaśne, Poczuj Miętę, Śmietankowe, Zbożowe. Niemal identyczne struktury występują na rynku ukraińskim: Ананасні, CoffeeLike, Chocolateria, Дюшес (od nazwy gatunku gruszek), Frulatto, FructoSio, Green Tea, Yogurtini (cukierki jogurtowe), Маричианчик, Nuttini (cukierki orzechowe), Медовий смак, Toffelini (cukierki o smaku toffi), Зимова вишня, Кавунові дольки ('plastry arbuza'), Herbina (cukierki ziołowe), Фрукты в шоколаде, Чорнослив з горіхом ('suszona śliwka z orzechami'), Mintex, Minties, Supermint, Барбарис ('berberys'), Біла ромашка ('rumianek'), Мальва, М'ятна ('mięta'), Sweet Souffle.

W opisie słodyczy, zwłaszcza w kontekście ich składu, nie może zabraknąć słowa mleko. Te nawiązania są częste: Mlekoladki, Milkizz, Mleczko Ulubione, Mleczko Familijne, Super Mleczko, Mleczko Królewskie, Alpejskie Mleczko, Mleczko waniliowe w czekoladzie, Kozie Mleczko. Wskazują one niewątpliwie na związek z utrwaloną już nazwą Ptasie Mleczko, do której używania ma prawo firma Wedel. Jest to zarazem marka wpisująca się w wyjątkowo popularny, tak w Polsce, jak i na Ukrainie, model tworzenia określeń słodyczy od nazw zwierząt. Wyjątkowe miejsce pośród nich zajmuje nazwa Krówka. Jej 
status proprialny $-\mathrm{z}$ uwagi na popularność, też zagraniczną, produktu — może budzić wątpliwości. Upowszechnienie nazwy pozwala zaliczyć ją do gatunku nazw zapelatywizowanych, gatunkowych ${ }^{7}$. Dlatego też polscy producenci wprowadzają do nazw dodatkowe wyróżniki: Krówka Ciagutka, Krówka Polska, Krówka Kakaowa, Krówka Śmietankowa, Krówka Wypasiona, Krówka Kruchutka, Krówki Krakowskie, Krówka Musli, Wesoła Mućka. Tak oznaczony produkt jest znany również u naszych sąsiadów pod nazwami: Корівка, Коровушка-Бурьонушка, Солоденька My, Star Cow, chociaż cieszy się mniejszą popularnością w przeciwieństwie do innych nazw z gatunku faunistycznych. W repertuarze określeń odzwierzęcych w Polsce występują rzeczowniki: jeż (Jeżyki), kukułka (Kukułka), miś (Miśki, Misiaczki), rak (Raczki), pszczoła (Pszczółka - marka główna, Pszczótki - submarka), biedronka (Biedroneczki). W ukraińskich z kolei: bażant (Золотий фазан), wiewiórka (Белочка-Затейница), niedźwiedź (Ведмедики), wiewiórka (Бурундучок), szpak (Сквориъь), żuk (Сонячний жук), сzajka (Чайка), pszczółka (Шалена бджілка). Ten rejestr dopełniają liczne określenia, które wskazują na odzwierzęcy kształt ciasteczek oraz żelków: Rekiny Ice (żelki wywołujące poczucie chłodu, w kształcie rekinów), Smoczki (lizaki w kształcie smoczków), Wąż-paje (żelki w kształcie węży i pająków), Miśki (żelki w kształcie misiów), Kocie Języczki (podłużne i wąskie czekoladki). Odbiorcą tak oznaczonych produktów jest $\mathrm{z}$ pewnością dziecko.

$\mathrm{Z}$ myślą o dorosłych konsumentach tworzy się nazwy wskazujące na zawartość alkoholu, przy czym w nazwach ukraińskich tego rodzaju informacja się nie pojawia. Na opakowaniu znajdujemy jedynie aluzje do określeń różnych gatunków alkoholu na poziomie submarki bis: Shooters chocolates (submarka firmy Roshen), Tequila Sunrise (submarka bis), Pina Colada (submarka bis), Brandy (submarka bis), Mapzapuma (submarka bis). W nazwach polskich odniesienia są oczywiste zarówno na poziomie submarki (Adwokatki, Adwokat, Wiśnie z alkoholem, Czekoladki z likierem, Premium Rum Pralines, Premium Liqueur Pralines, Premium Irish Cream Pralines, Aksamitny Advocat), jak i submarki bis (Likworki, Baltik Vodka - submarki bis firmy Bałtyk). Ponadto, w najnowszych polskich nazwach dokonuje się graficznych eksperymentów w rodzaju BeeMBER, z wpisaniem w nazwę bimber angielskiej wersji nazwy producenta — Pszczółka (por. ang. bee). To submarka cukierków o różnych smakach wódki, whisky, tequili, rumu.

Nazwy słodyczy jako komunikaty perswazyjne mogą również dosłownie sugerować wyśmienity smak produktu (Delicje, Pychatki, Pyszne; Delicia — ukraińska marka główna, Yummi Gummi, od ang. yummy 'pyszne, mniam'), a nawet fantastyczny (ukraińskie: Belissimo, Frutastick — lizaki firmy Roshen od hiszp. fruta 'owoc' i ang. stick 'pałka, laska', które wpisano najprawdopodobniej w strukturę

\footnotetext{
Artur Gałkowski (2008, s. 71) proponuje uznać tę nazwę za dechrematonim.
} 
ang. słowa fantastic, Super Kontik firmy Konti, HYPER; polskie: Faworytki). Mniej bezpośredni przekaz łączy obiekt z niebiańskim doświadczeniem (Podniebne Mleczko, Boska Krówka), godnym królów, a zatem bywalców najwyższych sfer (polskie: Royal, Baron Excellent, Eliteski; ukraińskie: Elitesse, Bestsellerini, Королівський шарм, Exclusive). Wyjątkowość konkretnych słodyczy uwypuklają nazwy nadające im nutę tajemniczości, a nawet baśniowości i wyimaginowania: Czekoladowe tajemnice, Fantazja, Magnetic, Pierniczki Baśniowe, Chochliki, Таинственная ночь ('tajemnicza noc').

Ważne miejsce w opisie jakości produktu zajmuje również kolorystyka. Poszczególne barwy niezmiennie od średniowiecza mają swoją symbolikę, a wśród nich najwyżej ceniona była i jest barwa złota. Już w XIV stuleciu sklepy bogatych paryskich cukierników nosiły nazwy: Pod Złotym Młotem czy Złota Broda (Toussant-Samat, 2002, s. 515). Tej barwy nie brakowało i nie brakuje też dzisiaj w tradycyjnych nazwach aptek: Pod Złotym Lwem, Pod Złotą Głową, Pod Złotym Jeleniem, Pod Złotym Smokiem (Rutkiewicz-Hanczewska, 2003, s. 177). Dawniej w przemyśle farmaceutycznym oraz w alchemii złoto uważane było za króla metali. Dziś pojawia się ono w nazwach słodyczy zarówno polskich: Golden Nut, Złote Michałki, Złote Praliny, Złoty Orzech, Złota Wiśnia, Złoty Adwokat, Złote Czekoladowe Kreacje, jak i ukraińskich: Golden Konti (firmy Konti), Золота лілія, Золота пташка, Золотий ключик, Золотий рачок, Золотий фазан, Золотий мак. O ile w polskich chrematonimach występuje tylko kolor złoty, o tyle ukraińskie nazwy wzbogacają ten wachlarz o barwę białą (Біла ромашка, Білий трюфель), czarną (Чорний мак, Черный прини), czerwoną (Червоний мак) i niebieską (Синій птах).

Smak i zawartość produktu to tylko niektóre parametry jego charakterystyki zawarte w chrematonimach. Istotne okazują się jeszcze kształt oraz wielkość, rozmiar produktu. Repertuar wspomnianych wcześniej form odzwierzęcych wzbogacony jest zatem o następujące: Serduszka, Kasztanki, Kamyki, Kule armatnie, Paluszki, Szyszki (polskie), MATT Balls (ukraińskie). Jeśli chodzi o wielkość, w nazwach znajdują się informacje typu: Mini (karmelki firmy Wolność), Mini Mix, Tyci Grześki (Grześki w mniejszej postaci), Prince Polo XXL (większy wafelek Prince Polo), Petite (ciastka submarki Любимов), Multi Cake Duo (ciastka marki Roshen), BisKonti (słodycze marki Konti). Uzupełnieniem tego opisu jest wskazanie na strukturę produktu (polskie: Krówka Ciagutka, ukraińskie: Cremini), funkcję (polskie: Musss... 'karmelki musujące'; Chrupki Orzech; Chrupper 'do chrupania'; ukraińskie: „Вкуся”» хрусткий 'chrupiący', Хрум, Хрустинка, Fizzy Boom 'musujący'), a nawet związek z aktywnym stylem życia: Sweet Active, Fit (polskie), Vita Mina, Стимул (ukraińska marka główna od czasownika stymulować).

\footnotetext{
${ }^{8}$ Cudzysłów jest w oryginalnej wersji nazwy; zawiera ona w podstawie rosyjski rzeczownik вкус , smak'.
} 


\section{WNIOSKI}

Nazwy polskich i ukraińskich słodyczy to komunikaty nazewnicze, które tworzy się z uwzględnieniem tych samych parametrów ich opisu (zob. poniższy rysunek). Informują one potencjalnego klienta o zawartości wyrobu, jego smaku, a także o typie i gatunku (pierniki, wafelki, cukierki itp.). To opis wnętrza produktu. Wskazówki na temat zewnętrznej strony wyrobu odnoszą się do faktury, kształtu, a także struktury i funkcji.

Kolejne elementy charakterystyki wykraczają poza fizycznie doświadczalny obiekt. Dotyczą bowiem jego cech rynkowych, a mianowicie zbliżają się w kierunku adresata, kreując w zasadzie jego immanentnie zaprogramowaną w nazwie postać. Nie tylko precyzują jego wiek i zainteresowania (kibic sportowy, student, dziecko, dorosły, osoba starsza), sugerują również porę dnia i roku, podczas której można kosztować określonych produktów. Doprecyzowują miejsce (dom, rodzina, piknik, koktajl, teatr, podróż) oraz okazję (imieniny, Dzień Babci, Dzień Dziadka) ewentualnej degustacji czy wręczenia słodkiego prezentu. Ostatecznie - głównie za pomocą innych nazw własnych, w tym symboli narodowych — podkreślają istotne wartości produktu spożywczego, którymi są lokalność, regionalizm i oryginalność.

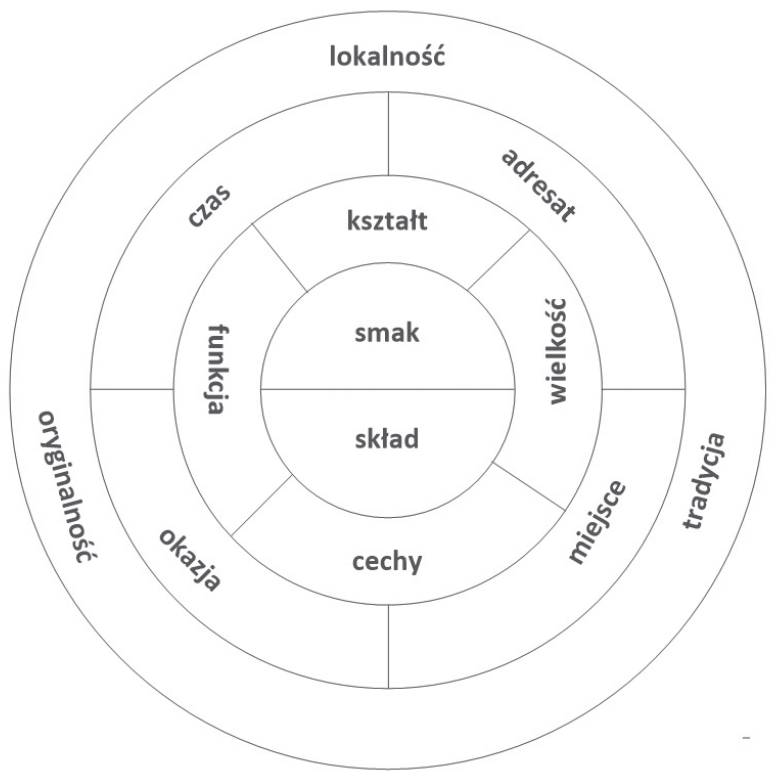

Treść komunikatu nazewniczego na przykładzie nazw słodyczy 
Nazwy ukraińskie ten regionalizm wyrażają na dwa sposoby: w nawiązaniach do dawnych nazw marek z czasów ZSRR i ich tłumaczeniu na język ukraiński oraz - $\mathrm{w}$ zdecydowanie mniejszym stopniu — w porównaniu $\mathrm{z}$ nazwami polskimi - przez nazwy od innych rodzimych propriów. W tej bowiem przestrzeni marketingowej bardzo popularne okazują się nazwy obcojęzyczne (głównie angielskie, ale także francuskie i włoskie), zarówno w grupie określeń odapelatywnych, jak i odproprialnych. Jest to spowodowane chęcią konkurowania na zachodnich rynkach zbytu, a także przekraczania granic grafii nieopartej na alfabecie łacińskim, dominującym w kulturze Zachodu. W nazewnictwie handlowym ukraińskim nie występują dosłowne nawiązania do zawartości alkoholu, być może w związku z istnieniem stereotypów w zakresie jego nadmiarowego spożycia przez mieszkańców wschodniej Europy. Szerzej reprezentowana jest kategoria nazw pochodzących od określeń kolorów (w Polsce odnotowano nazwy tylko z kolorem złota w podstawie) oraz tytułów utworów literackich i bohaterów bajek. Ponadto zwraca uwagę swoista dwujęzyczność ukraińsko-rosyjska nazewnictwa zamieszczanego na jednym produkcie, stanowiąca pokłosie długotrwałego związku Ukrainy z państwem rosyjskim, w wyniku którego kraj zamieszkują różne grupy etniczne: poza Ukraińcami także Rosjanie, członkowie innych narodowości byłego ZSRR oraz grupa ludzi identyfikujących się z dawnym porządkiem państwowym, z Rosją sowiecką.

Produkty spożywcze, do których zalicza się słodycze, reprezentują w obu charakteryzowanych kulturach zbliżone modele ich nazywania, wykorzystujące wszystkie możliwe parametry kreacji denotatu oraz jego odbiorcy. Różnice wynikają z odmiennej historii, polityki językowej, gospodarczej, odmienności dotyczących stosowanej grafii i mają charakter częściej ilościowy niż jakościowy.

\section{LITERATURA}

Gałkowski, A. (2008). Chrematonimy w funkcji kulturowo-użytkowej. Onomastyczne studium porównawcze na materiale polskim, włoskim i francuskim [Chrematonymy in the Cultural and Utility Function. Onomastic comparative study on Polish, Italian, and French material]. Łódź: Wydawnictwo UŁ.

Idzik ow ska, M. (2000). Imiona osobowe w roli chrematonimów (na przykładzie nazw artykułów handlowych) [Personal names as chrematonyms (on the example of the names of commercial items)]. W: M. Czachorowska i Ł.M. Szewczyk (red.), Onomastyka polska a nowe kierunki językoznawcze [Polish Onomastics and New Linguistic Trends] (s. 211-221). Bydgoszcz: Wydawnictwo Uczelniane WSP.

Jaros, V. (2011). Techniki nominacyjne w zakresie współczesnego nazewnictwa wyrobów piekarniczych i cukierniczych [Nomination techniques in the field of modern naming of bakery and confectionery products]. W: M. Biolik i J. Duma (red.), Chrematonimia jako fenomen wspótczesności [Chrematonymy as a Phenomenon of Modern Times] (s. 215-233). Olsztyn: Wydawnictwo UWM. 
Kalenûk, S. i Voronûk, K. (2018). Specifika leksiko-semantičnih grup čokonimiv ukraïns'koï movi [Specificity of lexical and semantic groups of choconyms in Ukrainian language]. Naukovi zapiski Nacional'nogo universitetu, "Ostroz'ka akademiâ". Seriâ Filologiâ, 1(69), 169-171.

Kosmeda, T. (2019). Interpretaciâ ìdeologemi „Ukraïns'ka mova” v sučasnomu rosìjs'komu movoznavstvì: „Mova, âk i priroda, ne maê zloï volì...” [Interpretation of the ideologeme "Ukrainian language" in modern Russian linguistics: "Language as well as nature has no evil intentions...". Lingvistični Studiï, 38, 78-83.

Laforet, S. i Saunders, J. (1994). Managing brand portfolios: How the leaders do it. Journal of Advertising Research, 34(5), 64-76.

Lech-Kirstein, D. (2011). Kreacje nazewnicze w nazwach drinków [Name creations in drink names]. W: M. Biolik i J. Duma (red.), Chrematonimia jako fenomen współczesności [Chrematonymy as a Phenomenon of Modern Times] (s. 283-292). Olsztyn: Wydawnictwo UWM.

Lučik, V.V. (2003). Hrematonimiâ (ergonimiâ) [Chrematonymy (ergonymy)]. W: E. Rzetelska Feleszko, A. Cieślikowa i J. Duma (red.), Stowiańska onomastyka [Slavic Onomastics] (t. II, s. 390-394). Warszawa-Kraków: Towarzystwo Naukowe Warszawskie.

Magda-Czekaj, M. (2011). Czy nazw herbat to chrematonimy? [Are the names of the teas chrematonymy]. W: M. Biolik i J. Duma (red.), Chrematonimia jako fenomen wspótczesności [Chrematonymy as a Phenomenon of Modern Times] (s. 311-318). Olsztyn: Wydawnictwo UWM.

Olszański, T.A. (2012). Problem językowy na Ukrainie. Próba nowego spojrzenia [The Language Issue in Ukraine. An attempt at a new perspective]. Warszawa: Ośrodek Studiów Wschodnich im. M. Karpia.

Pawlak, C. (2017). Konflikt na wschodzie Ukrainy i aneksja Krymu — standardowym przykładem działan hybrydowych [Conflict in the East Ukraine and the annexation of Crimea - a standard example of hybrid activities]. Rocznik Bezpieczeństwa Międzynarodowego, 11(1), 268-287.

Rutkiewicz-Hanczewska, M. (2003). Nazwy wiedeńskich aptek — schemat nazewniczy czy specyfika miejsca? [Names of Viennese pharmacies — naming model of specificity of the place]. Onomastica Slavogermanica, 24, 173-181.

Rutkiewicz-Hanczewska, M. (2007). Farmakonimy jako narzędzie brandingu [Drug names as a branding tool]. Język Polski, 87(3), 199-211.

Rutkiewicz-Hanczewska, M. (2013). Genologia onimiczna. Nazwa własna w płaszczyźnie motywacyjno-komunikatywnej [Onymic Genology. Proper name on motivational and communicational level]. Poznań: Wydawnictwo Poznańskie.

Rutkiewicz-Hanczewska, M. (2019). Nazwy w nazwach, czyli o współczesnych nazwach handlowych i granicach ich tworzenia [Names in names, or modern trade names and boundaries of their creation]. W: A. Chomová, J. Krško i I. Valentová (red.), Konvergencie a divergencie v propriálnej sfére [Convergence and Divergence in the Proprial Sphere] (s. 401-410). Banská Bystrica: Vydavatel'stwo Slovenskej Akadémie Vied VEDA.

Rutkowski, M. (2003). Nazwy na sprzedaż. O nazewnictwie na usługach marketing [Names for sale. On onomastics for marketing]. Onomastica, 48, 239-254.

Serczyk, W.A. (2009). Historia Ukrainy [History of Ukraine]. Wrocław: Zakład Narodowy im. Ossolińskich.

Stępniewski, T. (2016). Konflikt zbrojny Rosji z Ukrainą i negocjacje pokojowe w Mińsku [Russo-Ukrainian Armed Confl ict and Minsk Peace Talks]. Studia Europejskie, 3, 43-59.

Tomecka-Mirek, A. (2010). Leon i Elektryczna Pomarańcza, czyli o uwodzeniu nazwą. Tendencje w tworzeniu nazw soków, nektarów i napojów [Leon and An Electric Orange about trifling with the name. The tendencies in creating names of juices, nectars, and drinks]. W: R. Łobodzińska (red.), Nazwy własne i społeczeństwo [Proper Names and Society] (t. II, s. 357-370). Łask: Oficyna Wydawnicza „Leksem”.

Toussaint-Sa mat, M. (2002). Historia naturalna i moralna jedzenia [Natural and Moral History of Foods]. Warszawa: Wydawnictwo W.A.B. 
Wochelski, M. (2020). Historyczne i polityczne aspekty ukraińskiej drogi ku niepodległości [Historical and political aspects of Ukrainian way to independence]. Refleksje, 22, 71-86.

Yermolenko, S. i Zymovets', H. (2018). Some issues in research of eponymous business name motivation (with reference to Ukrainian onomasticon). Lingvistični Studiï, 36, 110-116.

Želâzkova, V.V. (2019). Ukraïns'komovnì čokonìmi u vimìrì semìotiki [Ukrainian choconyms in the dimension of semiotics]. Molodij včenij, 4.3(68.3), 100-103.

\title{
Netografia
}

W netografii zamieszcza się tylko strony, z których pochodzą zamieszczone w artykule ilustracje poszczególnych marek. Nie podaje się tu adresów witryn, z których wynotowano bazę nazw polskich i ukraińskich słodyczy z uwagi na ich liczbę.

https://skawa.com.pl (dostęp: 7.04.2021)

https://verbena.pl (dostęp: 7.04.2021)

https://krakuski.com.pl (dostęp: 7.04.2021)

https://goplana.pl (dostęp: 7.04.2021)

https://konti.ua (dostęp: 7.04.2021)

https://roshentrade.com.ua (dostęp: 7.04.2021)

https://millennium.dp.ua (dostęp: 7.04.2021)

\author{
SUMMARY \\ POLISH AND UKRAINIAN NAMES OF COMPANIES OF SWEETS AND THEIR PRODUCTS \\ IN A COMPARATIVE APPROACH
}

The subject of the article is the unique nature of Polish and Ukrainian names of sweets, the motives for their creation and the sociopolitical and cultural circumstances in which they were formed. Acomparative analysis showed that both Polish and Ukrainian names shape the image of these products in a similar way. They inform the potential customer about the interior of the product (i.e. the product content, its taste, as well as the type of sweets) and about its outer side, i.e. its texture, shape and function. Other elements of the characteristics go beyond the physically experienced object. They relate to its market characteristics and create the image of its recipients, inherently embedded in the product name, not only specifying their character (sports fans, students, children, adults, or the elderly), but also suggesting the season and time of day when particular products can be enjoyed. The names also specify the place and the occasion for possible tasting, emphasizing the important values of the food product: its local / regional character and its originality. Ukrainian names express regionalism in two ways: by reference to old brand names from the USSR times and by their translation into Ukrainian, and — to a much lesser extent, compared to Polish names — by endonyms. In the Ukrainian marketing space, in contrast with the Polish one, foreign names are also very popular. In Ukrainian brand names, names from color terms are more numerous, similarly to the titles of literary works and the names of their heroes.

Keywords: chrematonym, main brand, sub-brand, name of sweets, naming message 